Case report

\title{
NASAL TRANSMISSIBLE VENEREAL TUMOR IN A JACK RUSSEL TERRIER BITCH
}

\author{
FEGHIU Adrian ${ }^{1 *}$, CRÎNGANU Dan ${ }^{1}$, DUMITRESCU Florin ${ }^{1}$, PASCAL Manuela ${ }^{1}$, \\ VASILESCU Florina ${ }^{2}$, MILITARU Manuella ${ }^{1}$
}

${ }^{1}$ University of Agronomical Sciences and Veterinary Medicine of Bucharest, Romania, Faculty of Veterinary Medicine; ${ }^{2}$ National Institute for Research and Development in Pathology and Biomedical Sciences Victor Babes, Bucharest, Romania

(Received 16 $6^{\text {th }}$ April; Accepted $26^{\text {th }}$ December 2014)

A two-year old Jack Russell Terrier female with left-sided epistaxis was brought to the Clinic of the Bucharest Faculty of Veterinary Medicine. Endoscopy of the left nasal cavity revealed a cauliflower-like mass. Cytological and histopathological features were specific to canine transmissible venereal tumour (CTVT). Tumor tissue showed positive immunoreactivity to anti-vimentin monoclonal antibody (90\%) and Ki67 (35\%) and samples were negative for anti-cytokeratin monoclonal antibody. Chemotherapy with vincristine sulphate at a dose of $0.025 \mathrm{mg} / \mathrm{kg}$ i.v./week for 6 administrations was successful. This paper presents a primary form of nasal CTVT in a Jack Russell Terrier female.

Key words: canine transmissible venereal tumor, complex diagnosis, nasal localisation

\section{INTRODUCTION}

Canine transmissible venereal tumour (CTVT) is a malignant tumor transmitted naturally through a transplant of tumoral cells [1,2]. The main localisation is genital, CTVT affecting the vulva / vaginal vestibule of females and the penis in males [2]. The tumor can also present an extragenital localisation, appearing in the mouth, nasal cavities, eye and skin [1,2]. Tumor development through an implantation of tumoral cells in the mouth or nasal cavities is favoured by the particular behaviour of animals during the mating period (sniffing, licking and biting). The pattern of this neoplasm is a round cell sarcoma. Hematoxylin and eosin staining is observed in round cells arranged or grouped in cords interspersed with a rich connective stroma [2,3]. In this paper, we present a case of CTVT with intranasal localisation in a Jack Russell Terrier bitch assessed by several methods of examination and monitored for over 6 months.

Corresponding author: e-mail: afeghiu@yahoo.com 


\section{CASE PRESENTATION}

A two-year old Jack Russell Terrier female was brought to the Clinic of the Bucharest Faculty of Veterinary Medicine. The female had been suffering from left sided epistaxis for five months. Radiological examination was performed with a Röntgen device (Philips Optimus Bucky Diagnost). Endoscopy of the nasal cavities was performed using a Riester $\mathrm{GmbH} / 3920$ endoscope. For anaesthesia, the bitch was premedicated with $10 \mathrm{mg} / \mathrm{kg}$ medetomidine (Domitor ${ }^{\circledR}$, Pfizer) and $0.2 \mathrm{mg} / \mathrm{kg} \mathrm{im}$ butorphanol (Butomidor ${ }^{\circledR}$, Richter-Pharma). Anaesthesia was mantained with 1.5\% isoflurane (Anesteran ${ }^{\circledR}$, Rompharm Co.) on a Dragger Fabius anaesthetic machine. Cytology was performed on nasal secretions (from both nasal cavities) and fragments of tumour tissue harvested during endoscopy. Slides were stained with May Grunwlad Giemsa stain. For the histopathological examination, samples were fixed in a $10 \%$ formalin solution, embedded in paraffin, cut at $5 \mu \mathrm{m}$ and stained with haematoxylin and eosin. Immunohistochemistry (IHC) was performed on $5 \mu \mathrm{m}$ thick sections from $10 \%$ formalin-fixed paraffin-embedded tissues using the Streptavidin-Biotin (SABC) /Horseradish Peroxidase (HRP) method (StreptABC, Dako, Denmark). Monoclonal antibodies were used for this examination: anti-vimentin, anti-cytokeratin and antiKi67 antigen. Therapy consisted of six intravenous administrations of vincristine sulphate (Sindovin, Sindan Pharma Romania) at a dose of $0.025 \mathrm{mg} / \mathrm{kg} /$ week. Epistaxis is common in nasal forms of CTVT (Figure 1) [4-6]. Early haemorrhage is explained by particularities in the consistency and structure of the mass; CTVT is a well vascularised friable tumor par excellence [5,7]. The location presented in this paper has been previously reported by other authors [5-7]. The nasal form of CTVT has been diagnosed both in females and males. Its incidence is related to coital behaviour (licking, biting, sniffing). Radiography of the skull by rostro-caudal incidence revealed an area of increased radiopacity in the left frontal sinus. Increased radiopacity of the frontal sinus occurs in: sinusitis (with a bacterial, fungal or allergic aetiology), blockage of the sinus drainage with mucus accumulation and malignant tumours [8]. We believe the radiological imaging is not specific for the final diagnosis of CTVT, but this investigation is extremely important to assess the extent of lesions and bone invasion (a factor which leads to a poor prognosis). During endoscopy in the left nasal cavity the following lesions were found: abundant capillary bleeding, mucosal erosions, ulcers and multiple cauliflower-like friable lesions (Figure 2). Bleeding was more discreet in the right nasal cavity as compared to the left one. The rhinoscopy results are common for the following pathological processes: rhinitis and neoplasia. For the nasal localisation of CTVT, the gross lesions observed during rhinoscopy were described by Papazoglou et al. [4,5].

Groups of round cells with vacuolated basophilic cytoplasm, chromatin with granular appearance and 1-2 eccentrically located nucleoli were observed at the cytopathological examination. According to cytological criteria described by Anne Santos Amaral [9], we can state that the observed population was dominated by 
lymphocytoid type cells (Figure 3). The histopathological examination revealed round cells arranged or grouped in cords supported by a rich connective stroma. The neoplastic cells arrangement shows an arborescent layout (specific to CTVT), with a rich capillary network (Figure 4). According to the histopathological appearance, CTVT falls into the pattern of a round cell sarcoma $[3,10]$.

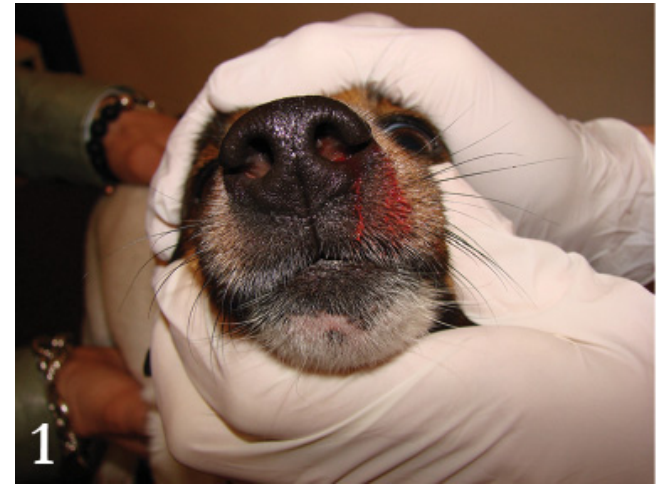

Figure 1. Clinical aspect, left-sided epistaxis

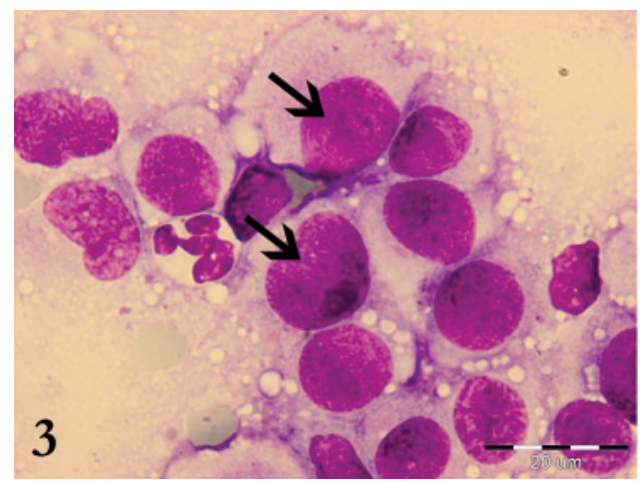

Figure 3. CTVT cytological appearance (May Grunwald Giemsa), 1000x, bar $20 \mu \mathrm{m}$. Round cells with anisocytosis and anisokariosis with granular chromatin (arrow tail) and eccentric nucleolus and cytoplasm with vacuoles

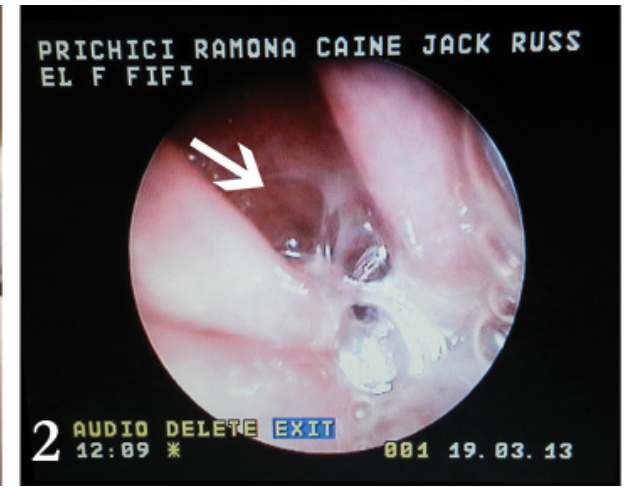

Figure 2. Endoscopy of the left nasal cavity. Common nasal meatus mucosa presents ulcerative lesions as well as a tumor mass (arrow)

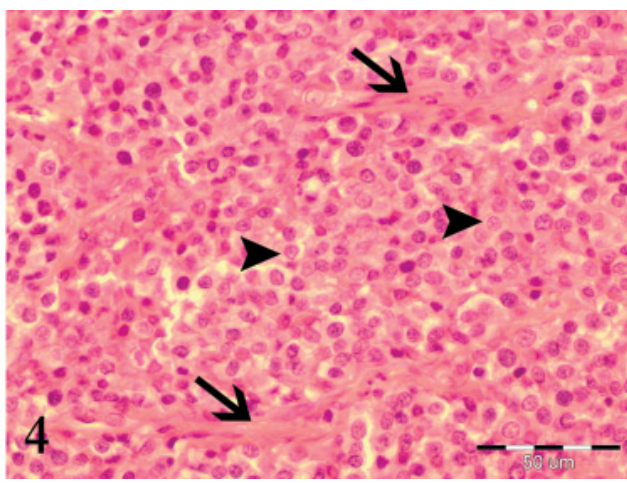

Figure 4. CTVT histopathologic aspect (HE), $400 \mathrm{x}$, bar $50 \mu \mathrm{m}$. Round cells arranged in rows (arrowhead) supported by a conjunctive stroma (arrow tail)

Samples were negative for immunostaining with AMC anti-cytokeratin (clone MNF116, Dako Glostrup Denmark). The tumor showed an intense immunoreactivity ( $90 \%)$ to AMC anti-vimentin (clone V9, Dako Glostrup Denmark). The immunohistochemical research carried out by Mozos (1996) and Marchal (1997) showed the reactivity of vimentin to be over $90 \%$ for CTVT and canine cutaneous histiocytoma $[11,12]$.

In our study there was an intense immunostaining of tumoral cells with anti-vimentin AMC clone V9 (Figure 5), which is consistent with literature reports. In the current 
study, immunostaining with Ki-67 antigen, clone MIB (Dako Glostrup, Denmark), showed a tumor proliferation index of $35 \%$ (Figure 6 ).

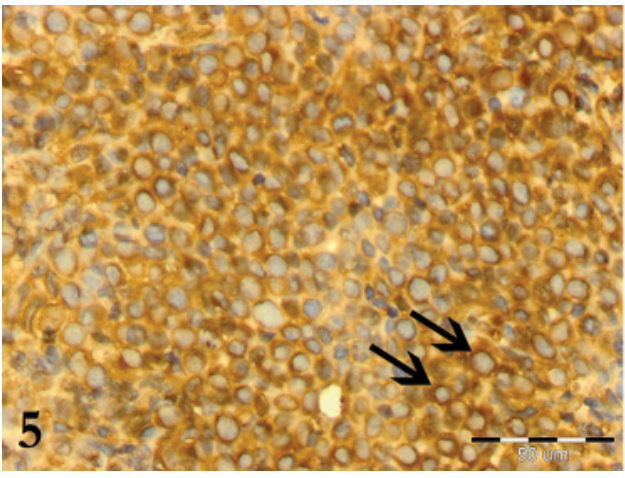

Figure 5. Vimentine positive ( $90 \%$ of the tumor cell cytoplasm - arrow) in CTVT nasal location (imunohistochemistry 400x, bar $50 \mu \mathrm{m})$

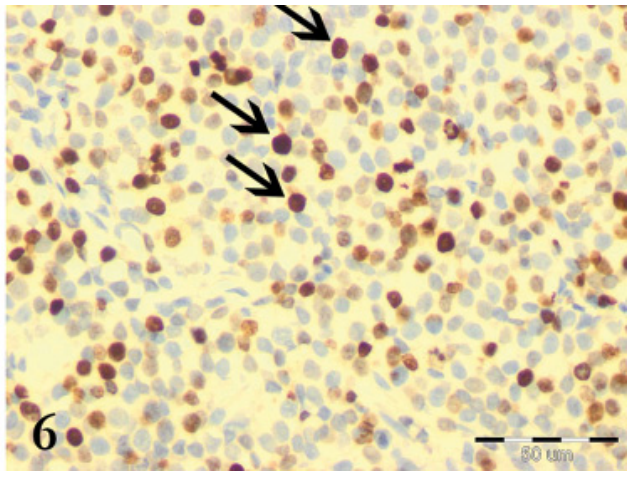

Figure 6. Ki-67 positive (35\% of tumor cell nuclei - arrow) in CTVT nasal location (imunohistochemistry, 400x, bar $50 \mu \mathrm{m}$ )

$\mathrm{Ki}-67$ antigen is a marker of cell cycle and cellular proliferation used to estimate the coefficient of proliferation in a cell population. Research has shown that the Ki-67 antigen plays an important role in assessing malignancy [13].

Therapy consisted of 6 doses of $0.025 \mathrm{mg} / \mathrm{kg}$ vincristine sulphate administered every 7 days. After the first two doses, relevant clinical signs (epistaxis and sneezing) began to subside. At the last check-up (30 days after the start of therapy), the animal did not present any clinical signs.

Six months after the treatment was completed the owner confirmed that the patient was in a good condition (it showed no clinical signs of disease) and that the diagnosis and the therapeutic approach had been successful. When comparing our results to existing data, we see similar outcomes [14].

The novelty of this work is the report of a nasal primary form of CTVT in a bitch. In the previous cases this localisation was most frequently diagnosed in males. There is no gender proneness for CTVT, the tumor occurring in both females and males. Nasal localisation of CTVT is more frequent in males due to behavioural features: licking, sniffing and biting of the genital region as well as of other body parts [15,16].

In the area where the animal presented in our study lives (the Bucharest metropolitan area) CTVT is frequently diagnosed in stray dogs, which provide the tumour with a continuous natural reservoir. We believe that in this case a stray dog may have been the source of contamination with tumoral cells.

\section{Acknowledgements}

This paper is written as part of the project POSDRU/107/1.5/S/76888 „Doctoral scholarships supporting research in agronomy and veterinary medicine" - USAMVB, 
the work is part of the doctoral thesis "Research on the epidemiology, morphology and biology of canine transmissible venereal tumour in dogs". We thank Professor Constantin Vlăgioiu for radiological investigation.

\section{REFERENCES}

1. Baştan A, Baki DA, Cengiz M: Uterine and Ovarian Metastasis of Transmissible Venereal Tumor in a Bitch. Turk J Vet Anim Sci 2008, 32(1): 65-66.

2. Das U, Das AK: Review of canine transmissible venereal sarcoma. Veterinary Research Commun 2000, 24: 545-56.

3. Feghiu A, Militaru M: Tumora veneriană transmisibilă canină. Rev Rom Med Vet 2013, 23: 2: 29-41 (article in Romanian with an abstract in English).

4. Levy E, Mylonakis ME, Saridomichelakis MN, Polizopoulou ZS, Psychogios V, Koutinas AF: Nasal and oral masses in a dog. Vet Clin Pathol 2006, 35: 115-118.

5. Papazoglou LG, Koutinas AF, Plevraki AG, Tontis D: Primary Intranasal Transmissible Venereal Tumour in the Dog: A Retrospective Study of Six Spontaneous Cases. J Vet Med A 2001, 48: 391-400.

6. Silva MCV, Daleck CR, Ramos RS, De Nardi AB, Martins MR, Calazans SG, Eurides: Primary Intranasal Transmissible venereal tumor with bone lysis of the maxilla and metastasis: Case Report. Ars Veterinaria Jaboticabal, SP 2007, 23: 1: 054-058.

7. Mylonakis ME, Saridomichelakis MN, Lazaridis V, Leontidesy LS, Kostoulasy P, Koutinas AF. A retrospective study of 61 cases of spontaneous canine epistaxis (1998 to 2001). Journal of Small Animal Practice 2008; 49: 191-196.

8. Forrest TL. The Granial and Nasal Cavities-Canine and Feline. In: Thrall ED, editor. Texbook of Veterinary Diagnostic Radiology. 4th ed. Philadelphia, USA: Saunders, 2002: pp. $73-75$.

9. Amaral AS, Gaspar LFJ, Bassani-Silva S, Rocha NS: Cytological diagnostic of transmissible venereal tumor in the Botucatu region, Brazil (descriptive study: 1994-2003). RPCV 2007, 99: (551): 167-171.

10. Thangathurai R, Balasubramaniam GA, Dharmaceelan S, Balachandran P, Srinivasan P, Sivaseelan S, Manohar BM: Cytological diagnosis and its histological correlation in canine transmissible venereal tumour. Vet Arhiv 2008, 78: 369-376.

11. Marchal T, Chabanne L, Kaplanski C, Rigal D, Magnol JP: Immunophenotype of the canine transmissible venereal tumour. Veterinary Immunology and Immunopathology 1997, 5: 1-11.

12. Mozos E, Mendez A, Gome C, Villamandos I, De Las Mulas MJ, Perez J: Immunohistochemical Characterization of Canine Transmissible Venereal Tumor. Vet Pathol 1996, 33:257-263.

13. Pena L, Nieto AI, Dolores PA, Cuesta P, Castano M: Immunohistochemical detection of Ki-67 and PCNA in canine mammary tumors: relationship to clinical and pathologic variables. J Vet Diagn Invest 1998, 10: 237-246.

14. Kumar A, Sangwan V, Mahajan SK, Singh ND, Singh K, Anand A, Saini NS: Transmissible Venereal Tumor Induced Paraphimosis in Dogs. Journal of Advanced Veterinary Research. 2012, 2: 48-49. 
15. Kennedy KC, Cullen JM, Edwards JF, Goldschmidt MH, Larsen S, Munson L, Nielsen S: Histological Classification of Tumors of the Genital System of Domestic Animals, second series volume IV, World Health Organization, International Histological Classification of Tumors of Domestic Animals,1998: 37-38.

16. Stockmann D, Ferrari HF, Andrade AL, Lopes RA, Cardoso TC, Luvizotto MCR: Canine Transmissible Venereal Tumors: Aspects Related to Programmed Cell Death, Braz J Vet Pathol, 2011 4(1): 67-75.

\title{
NAZALNI TRANSMISIVNI VENERIČNI TUMOR KOD KUJE RASE JACK RUSSEL
}

\author{
FEGHIU Adrian, CRINNGANU Dan, DUMITRESCU Florin, PASCAL Manuela, \\ VASILESCU Florina, MILITARU Manuella
}

Na klinici Fakulteta veterinarske medicine u Bukureštu, prezentovana je dve godine stara kuja rase Jack Russel sa epistaks krvavljenjem iz leve nozdrve. Endoskopijom leve nosne šupljine ustanovljena je masa karfiolaste strukture. Citološke i histopatološke karakteristike su odgovarale karakteristikama specifičnim za transmisivni venerični tumor (TVT) pasa. Tumor je bio imunohistohemijski pozitivan na anti-vimentin monoklonsko antelo (90\%) kao i na Ki67 (35\%), a negativan na anti-citokeratin monoklonsko antitelo. Hemoterapija sa vinikristin sulfatom, u dozi od $0.025 \mathrm{mg} / \mathrm{kg}$ telesne mase datog intravenski jedanput nedeljno, u trajanju od ukupno 6 nedelja, bila je uspešna. U radu se prikazuje primarna forma nazalnog TVT kod ženke rase Jack Russel terijera. 